\title{
The diagnosis of the technical condition of buildings as an indicator of the scale of needs for the revitalization on the example Kożuchów
}

\author{
Beata Nowogońska ${ }^{1, *}$ \\ ${ }^{1}$ University of Zielona Góra, Faculty of Civil Engineering, Architecture and Environmental \\ Engineering, ul. Z. Szafrana 1, 65-516 Zielona Góra, Poland
}

\begin{abstract}
In the revitalization process, the scope of work to be done depends on the technical condition of a particular historical site. Any activities should be preceded by a diagnosis of its technical condition in terms of changes which have taken place so far. The diagnosis of particular buildings will make it possible to determine the scope of needs to be included in the revitalization plan. The paper presents technical issues occurring in residential and commercial buildings and the problem of protection of cultural heritage as exemplified by the historical urban complex in Kożuchów.
\end{abstract}

\section{Introduction}

In building revitalization the scope of needs is determined by social and economic issues as well as by a diagnosis of the buildings to be renovated, which should take into account all the changes made to the buildings in the past. Current needs make it necessary to take a new approach to complexes of historical tenement houses. The idea of taking advantage of their historical value while adapting them to modern functions will help the Old Town to regain its identity $[1,2]$.

In the revitalization process, the scope of work to be done depends on the technical condition of a particular historical site [3, 4]. Any activities should be preceded by a diagnosis of its technical condition in terms of changes which have taken place so far $[5,6]$. The diagnosis of particular buildings will make it possible to determine the scope of needs to be included in the revitalization plan.

\section{Characteristics of the Old Town in Kożuchów}

The object of the research is a detached complex of buildings in a walled medieval town of a unique historical value in Kożuchów. The area has well-preserved borders in the form of fortifications. The thirteenth-century layout of the streets, the frontages of historical tenement houses, the monumental form of the church, the castle, the town hall, and the belt of ramparts give the old town an exceptional historical value.

* Corresponding author: b.nowogonska@,ib.uz.zgora.pl 
Kożuchów is one of the oldest towns in the Middle Oder Region. It is located in the place of a former fortified settlement which dates back to the early Middle Ages and which was part of the tribal state of Dziadoszanie. The settlement was located in the close proximity of the junction of important trade routes leading from Wrocław to Krosno. This advantageous location resulted in the development of a trading settlement in its vicinity, which already had its own church in 1125 . At the beginning of the thirteenth century Kożuchów was already a significant urban centre, consisting of scattered settlements: a fortified settlement, a trading settlement, a crafting borough with a church, a customs house, an inn, and a mill.

In the first half of the thirteenth century, during King Henryk Brodaty's reign, the boundaries of the town were laid out in a regular form. The town spread over a small area, its arrangement included a rectangular market surrounded by tenement houses with their plots, a square with a single-nave church and a cemetery. The tenement houses were situated in the front of the plots (with undeveloped backyards). The houses were expended later when the streets were formed. They all led to the market square and joined it at the right angle. At that time wooden bungalows were erected. They had passages to the backyards where there were vegetable gardens and outbuildings. Near the city, about 70 meters to the north, there was a castle and a water mill.

In 1253 Duke Konrad extended the town's rights by granting it the Magdeburg rights and also permitted the construction of fortifications. It is believed that ramparts and palisades were built around the town at that time. At the end of the thirteenth century the ramparts and the palisades were replaced with walls made of stones laid in layers. The walls in Kożuchów were over $8.0 \mathrm{~m}$ high and $1.5-1.9 \mathrm{~m}$ thick. They narrowed from the inside towards the top in steps creating a porch sheltered from the outside, which was approximately $1.0 \mathrm{~m}$ wide. The porch enabled communication between towers spaced around the perimeter of the walls at $48.0-58.0 \mathrm{~m}$. The towers were higher, they extended from the face of the walls, they were open from the inside and topped with wooden hoardings. The walls were surrounded by a $22.0 \mathrm{~m}$ wide moat and a $6.0 \mathrm{~m}$ high embankment. The town could be entered over wooden drawbridges crossing the moat. The town had four gates. In the fifteenth century, the defensive system was enhanced with a second circle of walls, which extended from the western wing of the castle to the Glogowska gate, and had semi-circular bastions. The gates consisted of two buildings connected with an enclosed footbridge leading across the moat. After the fire in 1764 a part of the fortifications was dismantled and used to rebuild the burnt houses.

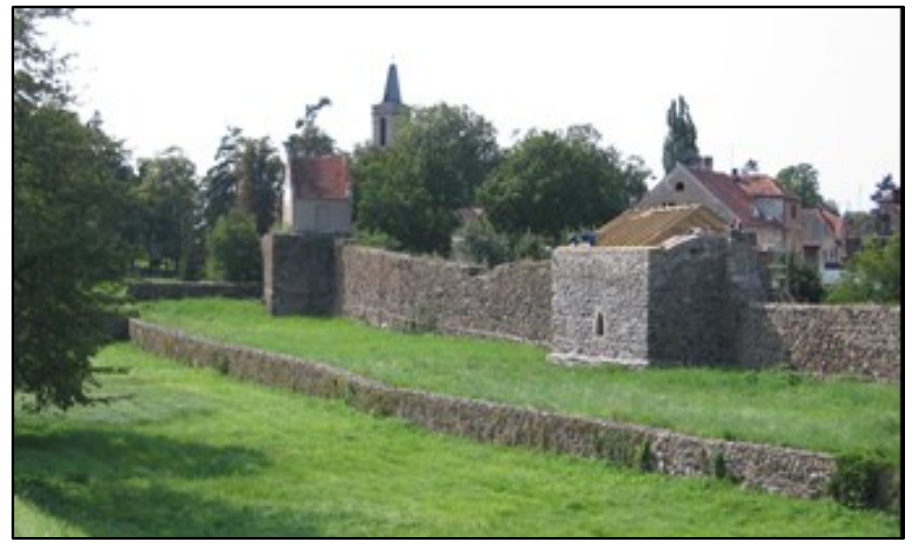

Fig. 1. The fortifications, a segment. The defensive walls have almost entirely been preserved; the moat, the outer ring of walls (photo by B. Nowogonska). 
In the middle ages, Kożuchów's economy was based mainly on crafts and trade. There were several strong guilds in the town, which included: drapers, weavers, furriers, butchers, blacksmiths, carpenters, brewers. The privileges that were bestowed on the town by the rulers of the Duchy stimulated its development. In the middle of the fifteenth, century Kożuchów was granted the right to mint its own coin. In the years 1340-1369, a new parish church was built with funds granted by Prince Henry V (the previous church burned down in 1339). A few years earlier, a hospital founded by Henry IV had been built next to the Church of the Holy Spirit, outside the town walls. In 1489, a new town hall was built, and the suburbs were expanded. At the turn of the fifteenth and the sixteenth centuries, the Duchy of Glogów, and Kożuchów had their heyday. Prince Sigismund Jagiellonczyk sent a strong unit of soldiers to the castle of Kożuchów. Their task was to combat banditry. In 1516, the castle came into the possession of John von Rechenberg. Under his rule, Lutheranism was introduced into the town.

In the fourteenth and fifteenth centuries, the pattern of narrow plots started to dominate. Buildings were located with their frontages facing the streets. After the fire in 1554, all the buildings around the market square were rebuilt of stone and brick. The basement walls and two floors above ground level have been preserved to this day. After another fire in 1764, the town authorities ordered to build three-storey buildings around the market square and two-storey ones outside the market.

The period of the Thirty Years' War was a difficult time for the town. After the war, Kożuchów lost many of its rights and privileges. However, the town was slowly rising from the fall. A large number of buildings were rebuilt, including the parish church and the town hall. In 1678, a water supply system was built. Water was taken from the surrounding hills. The suburbs also developed, e.g. the Protestants living in the town built their cemetery in one of them (today's lapidary). In 1709, a Protestant church was built outside the town walls, and a few years later - a school.

In the seventeenth century, the town suffered from numerous epidemics, crop failures and fires. During the seventeenth and the nineteenth centuries, the ongoing wars resulted in the economic decline of the town. The first textile factory in the town appeared as early as the late eighteenth century. In 1849, the town hall was expanded, and in 1869 a new hospital was opened.

The turn of the nineteenth and twentieth centuries witnessed further development of the suburbs, especially areas in the eastern part of the town. A railway station was built there in 1890. World War II did not have much impact on Kożuchów. After the war Kożuchów was still the seat of the county government. In 1953, the county of Kożuchów was abolished, and the seat of the local government was relocated to Nowa Sól.

\section{Characteristics of the complex of historical buildings}

The complex is characterised by a harmonious arrangement of plots and streets with traditional architecture, including three-storey buildings surrounding the market square and two-storey buildings along the other streets. The complex consists of more than 270 historical tenement houses, most of which are located on Gothic plots. Almost all of the frontages of the houses face the streets. The houses still have their former overall dimensions. A few Renaissance carved stone portals have been preserved on the façades of the sixteenth century buildings surrounding the market square. A trace of Baroque can be seen in a richly decorated relief depicting St. Peter and St. Paul, preserved on the façade of a building from the eighteenth century. 


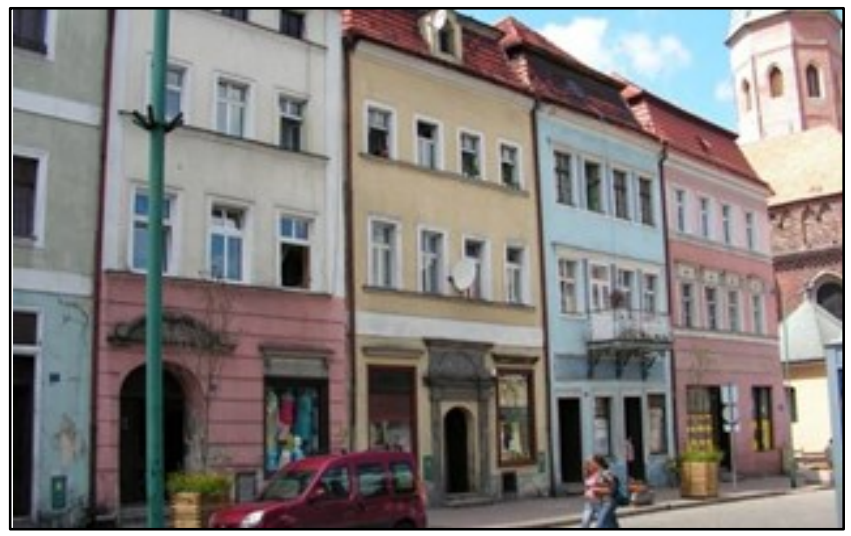

Fig. 2. The western frontage (photo by B. Nowogonska).

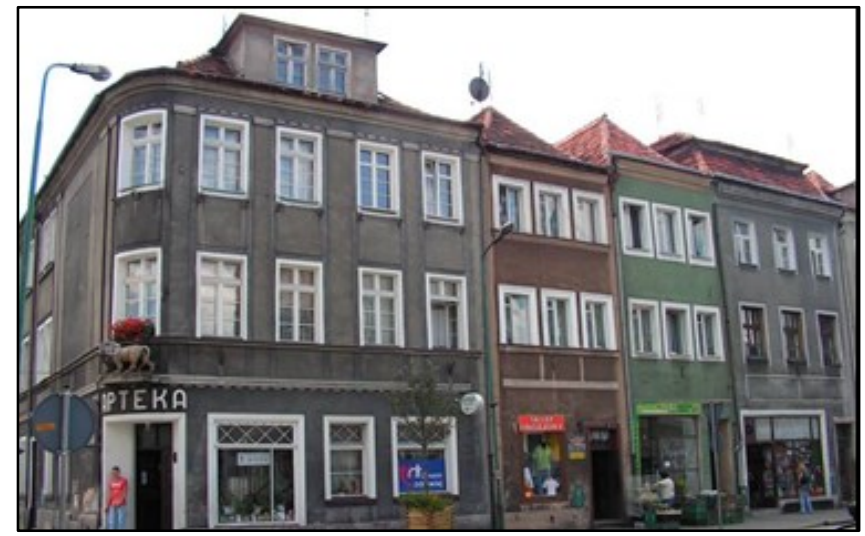

Fig. 3. The southern frontage (photo by B. Nowogonska).

All the buildings are based on an elongated rectangular plan, most of them consist of three sections. The ground level includes a passage to the backyard and a staircase, the front section - a trading or service area, and the back section - a large room called a rear chamber. They are covered with cross vaults and barrel or wooden ceilings.

The Old Town's complex was not seriously damaged during World War II. However, in the 1970's, it suffered much more damage than during the war. Several elements were deprived of their historical layout due to numerous deformations, and the present condition can be called spatial chaos.

In the twentieth century, three four-storey blocks of flats were built in the complex of old architecture (in the streets: Rynek, Klasztorna and Mickiewicza). They disturb the former spatial arrangement, visually overwhelm the nearby castle and spoil the panorama of this historical town. The buildings are located near the castle and their walls completely block the view. The original scale is also disturbed, because according to the widely known principle for complexes of old architecture, the highest and most impressive buildings were located in the market square in the centre, and the height of buildings decreased with the distance from the town centre. Four-storey buildings were built next to the three-and two-storey ones. 


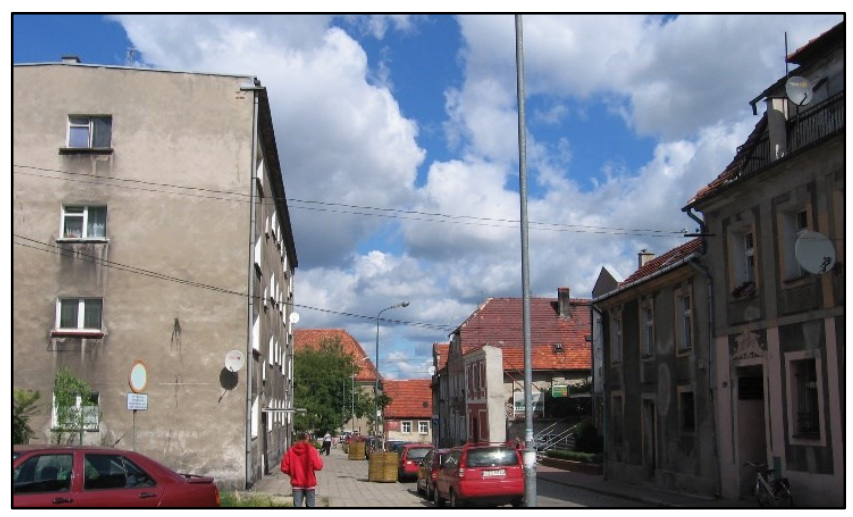

Fig. 4. A building from the 1970's (photo by B. Nowogonska).

There are voids in the spatial composition of the complex. Therefore, there is a need to integrate the existing buildings into a compact and complete urban complex by filling the voids with modern buildings, which would match the surrounding architecture. It is postulated that the complex should be restored to a form as close to the original as possible in order to preserve the historical character of the whole place.

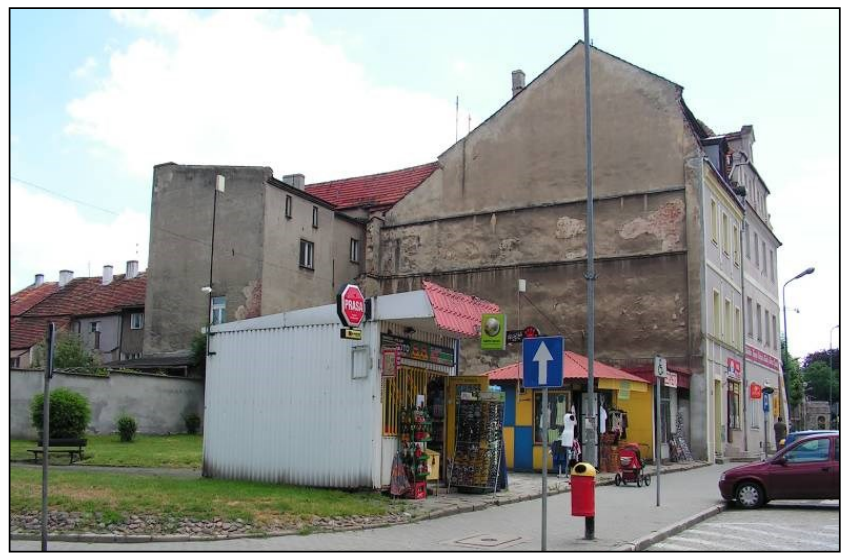

Fig. 5. Voids in the spatial composition, part of the eastern façade (photo by B. Nowogonska).

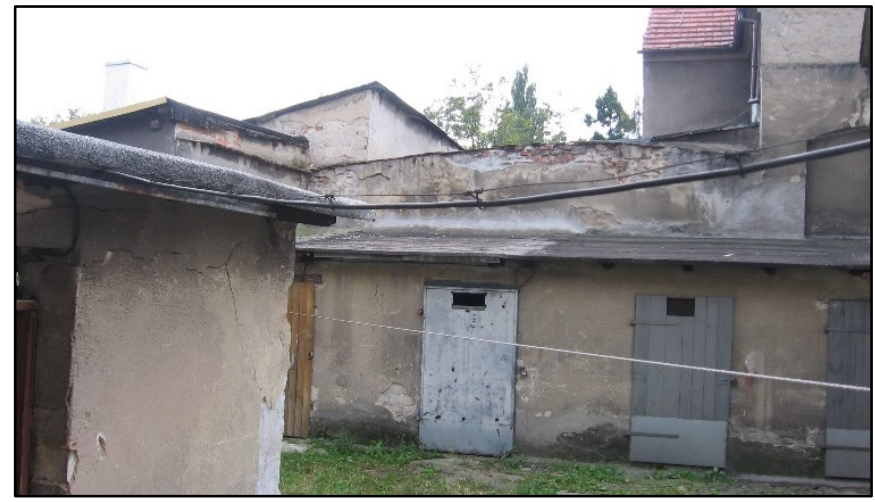

Fig. 6. An outbuilding planned to be demolished (photo by B. Nowogonska). 
Field studies showed that the buildings were in poor condition. They require numerous repairs such as: renovation, façade restoration, modernization, and expansion. It is necessary to carry out comprehensive restoration and to overhaul the whole old-town complex, complementing it and renovating all the architectural details.

\section{Diagnosis of buildings}

All the buildings of the old-town complex are characterised by similar material and structural solutions. There are differences only in the floor area, the number of storeys and the rafter structure (the collar beam structure prevails but sometimes the purlin structure can also be found). The walls of the examined objects are made of solid bricks and the ceilings of wooden beams. They also have wooden stairs and roof structure. The roofs are mostly covered with plain roofing tiles.

In a vast majority of the houses the basement walls are made of glacial boulders $(10-30 \mathrm{~cm}$ in diameter) and lime mortar. The walls of the storeys above ground level are made of solid burnt bricks of lime mortar or lime-clay (Class 7.5 - 10) with the dimensions $28 \times 14 \times 9 \mathrm{~cm}$ or less frequently $25 \times 12 \times 6 \mathrm{~cm}$. In all the buildings there is no horizontal and vertical insulation of the foundations or the basement walls.

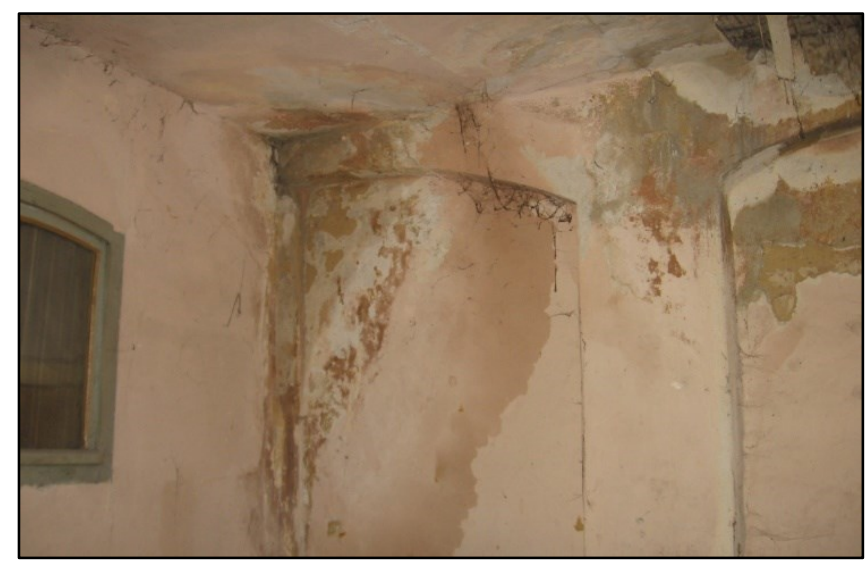

Fig. 7. Detail of the wall on the first floor in one of the houses. The dampness on the walls and the ceiling is due to the leaking roof valley. (photo by B. Nowogonska).

The basements are often covered with brick vaults, which are sometimes made of bricks supported by steel beams. The ground floors and the first floors have blind wooden ceilings. The beams of the ceilings are supported by external walls, and the ends of the beams are often affected by moisture. The stairs between the basement and the ground floor are made of bricks, and they do not have landings. Most of the buildings show signs of significant mechanical damage and the lack of ongoing maintenance.

In all the buildings, the roofs are wooden structures, covered with plain or cement tiles without any thermal insulation. Most frequently, the collar rafters are supported by two reinforcing walls made of pine timber. Often, there are numerous defects in the rafter structure. They were partly caused by the removal of some of the components during numerous roof modernizations or by significant biological corrosion. The following elements were found to be in the worst condition: the ends of the truss beams, the rafter beams and the wall plates. The L-shaped walls are very damp, and the wall plates are corroded. There are places with no wall plates, and the rafters rest directly on the walls. 
The window and door lintels are made as flat or segmented brick arches, in addition, they are connected with the basement vaults. On the ground floors (of commercial or service premises), there are also lintels made of steel. There are double hung sash windows, wooden doors and wooden gates (solid or panelled).

The flashings are made of galvanized steel sheets. The corroded roof valleys, the lack of gutters, and missing down pipes allow rain water to penetrate into the interiors, damage the exterior plaster and dampen the walls.

In general, it can be assumed that all the objects have suffered from similar damage, and there are similar problems with their technical condition, mainly:

- damp walls due to the lack of vertical and horizontal insulation of the basement walls;

- damp upper parts of the buildings due to the leaking roofs, gutters and down pipes;

- biological corrosion of wooden components such as: ceilings, stairs, roof trusses, windows, doors and flooring;

- lack of proper heating in the examined buildings;

- very poor technical condition of the buildings due to prolonged lack of maintenance.

\section{The scope of revitalization resulting from the diagnosis}

The revitalization should aim at the reconstruction of the historical landscape of the town by improving its composition and architectural form according to historical and aesthetic guidelines [1, 7-10]. Changes and corrections should be made to elements which are disharmonious, and which deform or disfigure the complex [11].

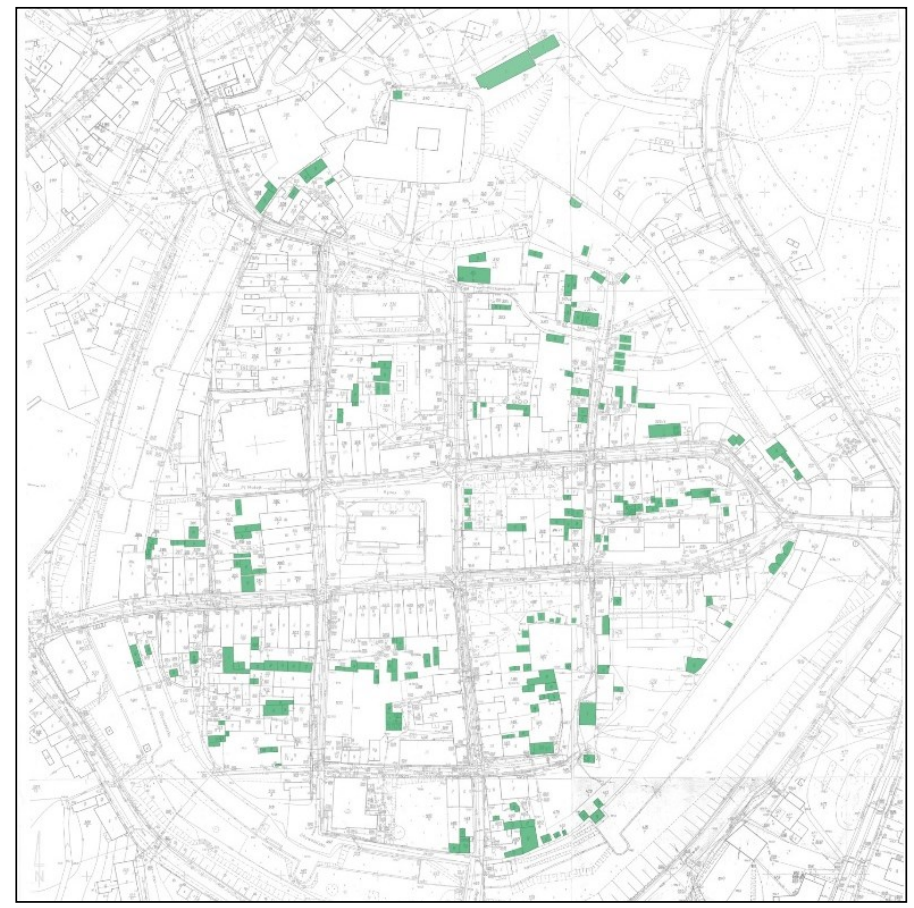

Fig. 8. The buildings planned to be demolished. 
The guiding principle of the revitalization should be to preserve the historical arrangement of the land plots, urban quarters and streets within the fortification walls. In order to properly direct the necessary transformation and modernization work, it is planned to remove elements of low historical and compositional value. It is postulated that the general plan of the area should be cleaned up by demolishing temporary objects, back-buildings, garages and outbuildings (in the following streets: Mickiewicza, Koscielna, Legnicka, Glogowska, Limanowskiego, Obywatelska, and Daszynskiego) [11]. However, a number of back-buildings, especially the ones that are intended to be modernized (in Krzywoustego street), should be preserved. In order to reproduce the spatial model of the Old Town, it is proposed to demolish the buildings which are disharmonious with the medieval layout of the streets (buildings at 19 Legnicka Street, 12 Mickiewicza Street and 2 Glogowska Street) [11].

It is also postulated that some buildings should be expanded, and that their architectural line should follow the original medieval pattern. It is also recommended that the four-storey buildings should be modernized, and that their architectural line in Klasztorna Street should be corrected. It is necessary to expand the commercial buildings in Daszynskiego Street to restore the original medieval building line in the street [11].

The goal of revitalization should be to protect historical buildings [1, 10]. The main principle is that remaining historical buildings should be preserved. According to the concept of revitalization, it is necessary to carry out revitalization work in buildings selected on the basis of the evaluation of their technical condition $[12,13]$. The scope of work to be done should include, in particular, the repair or replacement of the structure, roofing, gutters and down pipes, the revitalization of the façade, the dehumidification and desalination of the walls, the horizontal and vertical insulation of the foundations and the basement walls. Lack of repairs will result in further damage to other elements.

In addition, the revitalization has to comprise historical architectural details, both the existing ones and the ones that might be discovered in the process. Historical stonework and other details should be restored to their original location. $[1,7,10,12,13]$

If the true compositional value of the complex is to be restored, it is also necessary to modernise it. Modernization should include the improvement of the technical condition of the objects and the restoration of their original dimensions through reconstruction. The modernization of the building facades should include unveiling the layers and forms of their previous style as well as partial restoration of their architectural details. The facades could also be complemented with some contemporary elements, which would harmoniously fit into the historical structure of the Old Town. The number of changes made to historical objects in the process of modernization of the Old Town, which is included in the list of historical places, should be limited. Absolutely no damage can be done to architectural details, interior systems, canopies, staircases, etc.

While shaping urban landscape, it is necessary to be careful that the new infill buildings should be in harmony with the buildings that have been preserved [13-15]. In order to regain the historical urban arrangement, it is necessary to restore the historical look of the streets, squares, axes of view and the scenic routes of the town. Therefore, it is recommended to introduce a compact arrangement of buildings, to keep a suitable scale and dimensions, to use steep roofs, and to maintain the historical outlines of former structures. The proposed additions must not change the former, historical character and should avoid the falsification of history. It is recommended that the reconstruction of the historical Old Town should involve searching for contemporary architectural forms which will harmonize with the historical urban surroundings. Newly constructed buildings should not exceed the height or dimensions of the existing buildings. They should be built with the same spatial assumptions as the historical urban complex. 


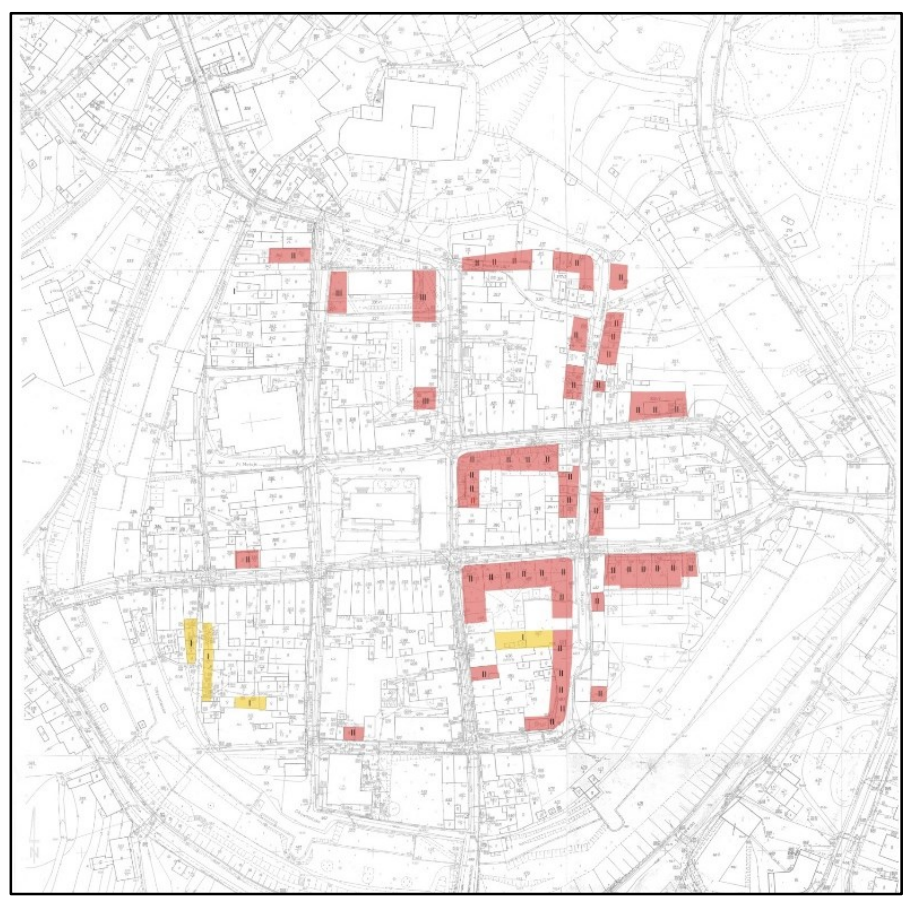

Fig. 9. Newly designed buildings.

However, the most important task is to show the old fortifications. It is planned to establish a tourist route going along the walls. It is recommended that the façade of the castle should be restored. Above all, the entryway to the castle, now located on a ground embankment crossing the moat, should be replaced with a wooden drawbridge that will reflect the military character of that place. The building located in the eastern part of the town, in the immediate vicinity of the moat, is planned to house a military museum. The embankment crossing the moat along the axis of the former town gate should be replaced with a brick and stone arcaded bridge. This will simultaneously maintain communications in that area of the town, make the moat more distinct and allow the tourist route to pass under the bridge.

\section{Summary}

The revitalization of the Old Town in Kożuchów should solve architectural problems. It should include the construction of communication lanes for both pedestrians and vehicles, as well as cleaning the existing green areas and designing new areas instead of the improperly used ones. However, first of all it should show the preserved fortifications. All the projects will probably be carried out, since the town authorities are determined to restore the fortified Old Town to its former condition and make it a tourist attraction.

The process of revitalization has to be coordinated and conducted jointly by the local government and the local community as an element of the town's development policy. In Kożuchów, the goal of that process is to prevent the degradation of urban space and to use the medieval fortress to attract tourists. Relics of the past may be a major tourist attraction in the whole region, and for this reason they play a significant role in the future of Kożuchów. The revitalization will contribute to qualitative changes by the stimulation of social and economic activities, the improvement of the environment and the preservation of national heritage. It will be carried out in compliance with the principles of sustainable development. 


\section{References}

1. Z.W. Paszkowski, K. Bizio, Revitalization in terms of depopulation of cities, (Proceedings of XXVIII Scientific-Technical Conference on Structural Failures, Szczecin-Międzyzdroje, pp. 75-95, 2017) [in Polish]

2. A. Ostańska, Civ. Environ. Eng. Rep. 18 (3), pp. 107-114 (2015)

3. E. Radziszewska-Zielina, G. Śladowski, J. Cult. Herit. 26, pp. 53-63 (2017)

4. R. Bucoń A. Sobotka, J Civ. Eng. and Manag. 21(7), pp. 893-901 (2015)

5. P. Knyziak, J. Krentowski, P. Bieranowski, MATEC Web Conf., 117, 00080 (2017)

6. J. Korentz, B. Nowogońska, MATEC Web Conf., 174, 01025 (2018)

7. J. Cibis, B. Nowogońska IOP Conf. Series: Mater. Sci. Eng., 245, 052060 (2017)

8. E. Radziszewska-Zielina, G. Śladowski, M. Sibielak, Automat. Constr., 84, pp. 242-257 (2017)

9. B. Nowogońska IOP Conf. Series: Mater. Sci. Eng., 471, 112034 (2019)

10. E. Malachowicz Maintenance and restoration of architectural and landscape teams (Publishing of University of Technology, Wrocław, 1994) [in Polish]

11. W. Eckert, P. Kochański, B. Nowogońska, Kożuchów - Old Town center revitalization program, study design, stage, (Design Studio PAF, Zielona Gora, 2014) [in Polish]

12. B. Nowogońska, Civ. Environ. Eng. Rep., 22, pp. 137-144 (2016)

13. W. Terlikowski, E3S Web of Conf., 49, 00116 (2018)

14. B. Nowogońska J. Cibis, IOP Conf. Series: Mater. Sci. Eng., 245, 052042 (2017)

15. B. Ksit, M. Gaczek, E3S Web of Conf., 49, 00062 (2018) 